\title{
Gastrointestinal tolerability with ibandronate after previous weekly bisphosphonate treatment
}

\author{
This article was published in the following Dove Press journal: \\ Clinical Interventions in Aging \\ 7 September 2009 \\ Number of times this article has been viewed
}

\author{
Richard Derman' \\ Joseph D Kohles \\ Ann Babbitt ${ }^{3}$ \\ 'Department of Obstetrics \\ and Gynecology, Christiana Hospital, \\ Newark, DE, USA; ${ }^{2}$ Roche, Nutley, \\ NJ, USA; ${ }^{3}$ Greater Portland Bone \\ and Joint Specialists, Portland, \\ ME, USA
}

\begin{abstract}
Data from two open-label trials (PRIOR and CURRENT) of women with postmenopausal osteoporosis or osteopenia were evaluated to assess whether monthly oral and quarterly intravenous (IV) ibandronate dosing improved self-reported gastrointestinal (GI) tolerability for patients who had previously experienced GI irritation with bisphosphonate (BP) use. In PRIOR, women who had discontinued daily or weekly BP treatment due to GI intolerance received monthly oral or quarterly IV ibandronate for 12 months. The CURRENT subanalysis included women receiving weekly BP treatment who switched to monthly oral ibandronate for six months. GI symptom severity and frequency were assessed using the Osteoporosis Patient Satisfaction Questionnaire ${ }^{\mathrm{TM}}$. In PRIOR, mean GI tolerability scores increased significantly at month 1 from screening for both treatment groups (oral: 79.3 versus 54.1; IV: 84.4 versus 51.0; $\mathrm{p}<0.001$ for both). Most patients reported improvement in GI symptom severity and frequency from baseline at all post-screening assessments ( $>90 \%$ at Month 10). In the CURRENT subanalysis $>60 \%$ of patients reported improvements in heartburn or acid reflux and $>70 \%$ indicated improvement in other stomach upset at month 6. Postmenopausal women with GI irritability with daily or weekly BPs experienced improvement in symptoms with extended dosing monthly or quarterly ibandronate compared with baseline.
\end{abstract}

Keywords: ibandronate, osteoporosis, bisphosphonate, gastrointestinal

\section{Introduction}

Declining postmenopausal estrogen levels lead to an increase in bone turnover and a decrease in bone mass. The resulting osteoporosis is a cause of substantial morbidity, reduction in quality of life, and increased mortality. ${ }^{1,2}$ Bisphosphonates (BPs), which are the treatment of choice, have proven efficacy in terms of bone turnover marker reduction, bone mineral density increase, and fracture risk reduction. ${ }^{3-6}$ However, their effectiveness in clinical practice is often compromised by poor adherence to dosing instructions and poor persistence with treatment. ${ }^{7}$

Treatment discontinuation is associated with increased risk of fractures ${ }^{8-10}$ and has been attributed to several causes, including patients' experience of gastrointestinal (GI) side effects, such as esophageal irritation and ulceration, associated with oral BPs. ${ }^{1-13}$ The GI irritation observed with oral BPs is a result of direct contact between the drug and gastric mucosa. ${ }^{14}$ BPs act as topical irritants on the gastric mucosa, leading to mucosal necrosis. ${ }^{15}$ The effects can be minimized by following the dosing instructions, which are intended to minimize direct contact. ${ }^{16}$ Less frequent administration may also help by allowing time for the gastric mucosa to recover between doses. In a database study, the risk of severe GI events was significantly lower for patients treated 
with ibandronate than with weekly BPs. ${ }^{17}$ However, this study did not assess milder GI symptoms. The rate of GI adverse events was similar to placebo with all BPs in a number of randomized clinical trials (RCTs), ${ }^{4,5-21}$ in contrast to reports supporting a link between BP treatment and GI symptoms from routine clinical practice. ${ }^{12,22}$ This difference may reflect the generally healthier populations typically included in clinical trials compared with those treated in routine clinical practice, or factors such as better compliance with dosing instructions in clinical trials or under-reporting of adverse events in clinical trials.

Ibandronate, a nitrogen-containing BP indicated for prevention and treatment of postmenopausal osteoporosis, is available as monthly oral and quarterly intravenous (IV) formulations, ${ }^{23,24}$ thus allowing for the evaluation of GI symptoms with extended BP dosing regimens. The purpose of this investigation was to consider data from two clinical trials of ibandronate in order to assess whether extended BP dosing was associated with improved GI tolerability for patients who indicated previous GI irritation with daily or weekly BP use using self-reported questionnaires with questions specifically addressing GI symptoms.

\section{Materials and methods}

\section{Study design}

The frequency and severity of GI symptoms with ibandronate were assessed using questionnaires in two openlabel, multicenter clinical trials, PRIOR $^{25}$ and CURRENT. ${ }^{26}$ PRIOR was a 12-month study that enrolled women who had discontinued daily or weekly BP treatment due to GI symptoms at least three months previously. The participants chose to receive either the $150 \mathrm{mg}$ monthly oral or $3 \mathrm{mg}$ quarterly IV ibandronate dose. CURRENT was a large, prospective, open-label, multicenter, six-month study designed to identify the level of patient satisfaction with once-monthly BP therapy in patients previously treated with weekly BPs, using the validated Osteoporosis Patient Satisfaction Questionnaire (OPSAT-Q) ${ }^{\mathrm{TM}} \cdot{ }^{27}$ In PRIOR, all patients were required to take supplemental calcium and vitamin D for the full duration of the study and the sponsor provided patients with a combination dietary supplement containing vitamin D 200 IU and elemental calcium $500 \mathrm{mg}$. In CURRENT, all patients were instructed to take supplemental calcium and vitamin D for the full duration of the study. In both studies, patients were instructed to take calcium and vitamin $\mathrm{D}$ in divided daily doses with a meal. Under no circumstances was the patient to take calcium, vitamin D, any other medication, or food/beverage (except water) together with study drug or during the predose or postdose fasting period.

\section{Participants}

All patients from PRIOR were included in this analysis. PRIOR recruited women who had discontinued previous daily or weekly BP treatment at least three months earlier due to GI intolerance.

The present analysis included data from a subset of patients from the CURRENT study with GI symptoms on weekly BPs at enrollment, who then received monthly oral ibandronate $150 \mathrm{mg}$ for six months. ${ }^{28}$ CURRENT included women currently receiving weekly BP treatment who switched to monthly ibandronate. Patients with contraindications to calcium or vitamin $\mathrm{D}$; inability to stay in an upright position for 60 minutes; history of hypercalcemia, renal disease, or liver disease; and a history of major upper GI disease (significant upper GI bleeding within the last year requiring hospitalization or transfusion; recurrent peptic ulcer disease documented by radiographic or endoscopic means; dyspepsia or gastroesophageal reflux uncontrolled by medication; abnormalities of the esophagus that delay esophageal emptying, such as stricture, achalasia, or dysmotility; and active gastric/duodenal ulcers) were excluded from CURRENT.

Patients who reported GI symptoms at baseline in CURRENT were identified for the present subanalysis

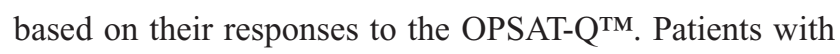
an OPSAT-Q ${ }^{\mathrm{TM}}$ score of 1 to 4 on 1 or more of the following questions: 11, 12, 14, 15 were included in the analysis (Figure 1).

\section{Assessments}

GI symptoms were assessed with questions selected from the OPSAT-Q ${ }^{\mathrm{TM}}$ in both trials (Figure 1). Scores from the selected OPSAT-Q ${ }^{\mathrm{TM}}$ questions were compared at screening (previous treatment) and months 1, 4, 7, and 10 in PRIOR, and at screening and month 6 in CURRENT. A five-point scale was used for each question. In PRIOR, a score of 1 for questions 11 to 13 indicated an answer of "extremely bothered," while a score of 5 specified that the patient was "not bothered at all." Similarly, for questions 14 to 16 , which dealt with the frequency of GI symptoms, a score of 1 was awarded for an answer of "more than 3 days" and 5 for an answer of "0 days."

\section{Statistical analysis}

The proportions of patients who reported improved, worsened, or unchanged GI symptoms on the OPSAT- $\mathrm{Q}^{\mathrm{TM}}$ questions at 


\section{Questions regarding severity of side effects*}

Screening: How bothered are you by the following side effects that you may or may not experience after taking your previous osteoporosis/osteopenia medication? If you have never experienced the side effect from the medication, please answer "Not at All Bothered."

Treatment Phase: How bothered are you by the following side effects that you may or may not experience after taking your current osteoporosis/osteopenia medication? If you have never experienced the side effect from the medication, please answer "Not at All Bothered."

\begin{tabular}{|lcc|}
\hline & PRIOR & CURRENT \\
\hline 11. Heartburn or acid reflux & $\mathrm{X}$ & $\mathrm{X}$ \\
\hline $\begin{array}{l}\text { 12. Stomach upset other than heartburn } \\
\text { or acid reflux (such as diarrhea, nausea, } \\
\text { vomiting, or stomach pain) }\end{array}$ & $\mathrm{X}$ & - \\
\hline $\begin{array}{l}\text { 13. Any other side effects you think are related } \\
\text { to your osteoporosis medication }\end{array}$ & \\
\hline $\begin{array}{l}\text { Scale of "Not at all bothered", "Slightly bothered", } \\
\text { "Moderately bothered", "Quite a bit bothered", } \\
\text { "Extremely bothered" }\end{array}$ & \\
\hline
\end{tabular}

\section{Questions regarding frequency of side effects*}

Screening: When on medication, approximately how many days per month did you experience the following side effects associated with your osteoporosis/osteopenia medication?

Treatment Phase: When on medication during the last 4 weeks, approximately how many days per month did you experience the following side effects associated with your osteoporosis/osteopenia medication?

\begin{tabular}{|lcc|}
\hline & PRIOR & CURRENT \\
\hline 14. Heartburn or acid reflux & $\times$ & $\mathrm{X}$ \\
\hline $\begin{array}{l}\text { 15. Stomach upset other than heartburn } \\
\text { or acid reflux (such as diarrhea, nausea, } \\
\text { vomiting, or stomach pain) }\end{array}$ & $\mathrm{X}$ & - \\
\hline $\begin{array}{l}\text { 16. Any other side effects you think are related } \\
\text { to your osteoporosis medication }\end{array}$ & $\mathrm{X}$ \\
\hline Scale of "0 days", "1 day", "2 days", "3 days", "More than 3 days" & \\
\hline
\end{tabular}

Figure I Questions from the Osteoporosis Patient Satisfaction Questionnaire ${ }^{\mathrm{TM}}$ (OPSAT-Q ${ }^{\mathrm{TM}}$ ) used to assess gastrointestinal symptoms in the PRIOR and CURRENT studies. Notes: *Question numbers refer to the numbers in the complete OPSAT-Q ${ }^{\text {TM }}$. ( ) for the OPSAT-Q Roche Laboratories, Inc. All Rights Reserved.

the end of the study compared with screening were analyzed for both studies. Additionally, for PRIOR, OPSAT-Q ${ }^{\mathrm{TM}}$ responses were transformed into an overall GI tolerance score on a scale of 0 to 100 , with a higher GI tolerability score indicating less frequent and/or less severe symptoms:

GI tolerance score

(Sum of actual scores - Sum of lowest possible scores) $\times 100$ Sum of highest possible scores

Within-group comparisons of GI tolerance scores in PRIOR were conducted using $t$-tests.

\section{Results}

\section{Patient demographics and baseline characteristics}

Demographic and baseline characteristics are summarized in Table 1. In total, 147 participants in PRIOR (27.1\%) chose oral and $396(72.9 \%)$ chose IV ibandronate. The participants' mean age was 65.7 years in the oral treatment group and 66.2 years in the IV treatment group. Most participants had a diagnosis of osteoporosis (84 oral [57.1\%], 286 IV [72.2\%]); the rest of the study population had a diagnosis of osteopenia. Detailed demographic and baseline data have been presented elsewhere. ${ }^{25}$ 
Table I Baseline and demographic characteristics

\begin{tabular}{|c|c|c|}
\hline Characteristic & $\begin{array}{l}\text { PRIOR: All } \\
\text { participants } \\
(\mathbf{N}=543)\end{array}$ & $\begin{array}{l}\text { CURRENT: } \\
\text { participants } \\
\text { who reported } \\
\text { GI symptoms } \\
\text { during screening } \\
(n=89)\end{array}$ \\
\hline \multicolumn{3}{|l|}{ Race } \\
\hline White/Caucasian & $508(94)$ & $82(92)$ \\
\hline Black & $15(3)$ & $4(4)$ \\
\hline Other & $20(4)$ & $3(3)$ \\
\hline \multicolumn{3}{|l|}{ Age, years } \\
\hline $\mathrm{n}$ & 543 & \\
\hline Mean \pm SD & $66.0 \pm 10.55$ & $63.6 \pm 10.62$ \\
\hline Range & $37-99$ & $4 I-86$ \\
\hline \multicolumn{3}{|l|}{ Weight, kg } \\
\hline $\mathrm{n}$ & 540 & \\
\hline Mean \pm SD & $65.0 \pm 12.32$ & \\
\hline Range & $37-125$ & \\
\hline \multicolumn{3}{|l|}{ Height, cm } \\
\hline $\mathrm{n}$ & 541 & \\
\hline Mean \pm SD & $159.8 \pm 6.88$ & \\
\hline Range & $130-182$ & \\
\hline \multicolumn{3}{|l|}{ BMI, kg/m² } \\
\hline $\mathrm{n}$ & 539 & \\
\hline Mean \pm SD & $25.5 \pm 4.88$ & $25.8 \pm 5.36$ \\
\hline Range & $14-49$ & $17.8-42.1$ \\
\hline \multicolumn{3}{|l|}{ Highest level of education } \\
\hline Elementary school & II (2) & \\
\hline Some high school & $35(6)$ & \\
\hline High school graduate/GED & $|4|(26)$ & \\
\hline Some college & $170(3 \mid)$ & \\
\hline College graduate & $130(24)$ & \\
\hline Postgraduate degree & $56(10)$ & \\
\hline \multicolumn{3}{|l|}{ Current occupation } \\
\hline Not working & $370(68)$ & \\
\hline Working & $173(32)$ & \\
\hline \multicolumn{3}{|l|}{$\begin{array}{l}\text { Major risk factors for } \\
\text { osteoporosis }\end{array}$} \\
\hline Low body weight (<58 kg) & $184(33.9)$ & $26(29.2)$ \\
\hline History of fractures as an adult & $174(32.0)$ & $32(36.0)$ \\
\hline $\begin{array}{l}\text { History of fragility fracture } \\
\text { in Ist degree relative }\end{array}$ & $126(23.2)$ & $15(16.9)$ \\
\hline Current smoker & $60(11.0)$ & II (I2.4) \\
\hline $\begin{array}{l}\text { Use of oral corticosteroid } \\
\text { therapy for }>3 \text { months }\end{array}$ & $53(9.8)$ & $5(5.6)$ \\
\hline None of above & $168(30.9)$ & $24(27.0)$ \\
\hline \multicolumn{3}{|l|}{ Primary diagnosis } \\
\hline Osteoporosis & $370(68.1)$ & $63(70.8)$ \\
\hline Osteopenia & 173 (31.9) & $26(29.2)$ \\
\hline
\end{tabular}

Table I (Continued)

\begin{tabular}{|c|c|c|}
\hline Characteristic & $\begin{array}{l}\text { PRIOR: All } \\
\text { participants } \\
(\mathbf{N}=543)\end{array}$ & $\begin{array}{l}\text { CURRENT: } \\
\text { participants } \\
\text { who reported } \\
\text { GI symptoms } \\
\text { during screening } \\
(n=89)\end{array}$ \\
\hline \multicolumn{3}{|l|}{$\begin{array}{l}\text { Months since diagnosis, } \\
\text { mean } \pm \text { SD }\end{array}$} \\
\hline Osteoporosis & - & $\begin{array}{l}57.1 \pm 50.24 \\
(n=63)\end{array}$ \\
\hline Osteopenia & - & $\begin{array}{l}36.4 \pm 23.63 \\
(n=26)\end{array}$ \\
\hline \multicolumn{3}{|l|}{$\begin{array}{l}\text { Months since stopping } \\
\text { alendronate or risedronate }\end{array}$} \\
\hline Mean \pm SD & $23.4 \pm 25.82$ & - \\
\hline Range & $1.4-144.0$ & - \\
\hline \multicolumn{3}{|l|}{ GI tolerance score } \\
\hline 0 to $<25$ & $65(12.0)$ & \\
\hline 25 to $<50$ & $168(31.1)$ & \\
\hline 50 to $<75$ & $207(38.3)$ & \\
\hline 75 to $\leq 100$ & $100(18.5)$ & \\
\hline Total reported & 540 & \\
\hline $\begin{array}{l}\text { Taking osteoporosis/osteopenia } \\
\text { medication }\end{array}$ & 0 & $89(100)$ \\
\hline $\begin{array}{l}\text { Years of taking osteoporosis/ } \\
\text { osteopenia medication, } \\
\text { mean } \pm S D(n=87)\end{array}$ & - & $2.4 \pm 1.9$ \\
\hline
\end{tabular}

Note: Data presented are number (\%) unless otherwise noted.

Abbreviations: GED, general education development; Gl, gastrointestinal; $\mathrm{SD}$, standard deviation.

In the CURRENT study, participants with GI symptoms at baseline were identified by a score of 1 to 4 on at least 1 of the relevant OPSAT-QTM questions. Overall 438, 339, 231, and 159 women had a score of at least 1 on questions $11,12,14$, and/or 15 , respectively. Detailed demographic and baseline data have been presented elsewhere. ${ }^{28}$

\section{Gl symptoms}

In PRIOR, over $75 \%$ of participants in both the oral and IV groups reported $\geq 10 \%$ increase in GI tolerability scores at all post-screening evaluations compared with screening (oral range: $77.9 \%-85.5 \%$; IV range: $83.7 \%-85.8 \%$ ). The majority of patients reported improvement in symptom severity scores (questions 11-13) from baseline at all post-screening assessments, with $>70 \%$ of participants indicating improvement at month 1 . The pattern of improvement in GI symptom frequency scores (questions 14-16) was similar to that in GI symptom severity scores. Over $90 \%$ of participants in each group reported improvements on 
each question at month 10 (Figure 2). Mean GI tolerability scores were significantly higher at month 1 compared with screening for both the oral and IV treatment groups (oral: 79.3 versus 54.1; IV: 84.4 versus 51.0, respectively; $\mathrm{p}<0.001$ for both groups). The scores continued to increase for both groups at months 4,7 , and 10 and remained significantly higher compared with screening scores at all assessment points ( $\mathrm{p}<0.001$ for both groups).

A similar result was observed in the CURRENT study, where the majority of women with GI symptoms on their current weekly BP indicated improvements in degree of bother and frequency of GI symptoms six months after switching to monthly oral ibandronate (Figure 3). Over 60\% of patients reported improvements in heartburn or acid reflux (bother: 62.6\%; frequency: 66.4\%) and over 70\% indicated an improvement in stomach upset other than heartburn or acid reflux (bother: $72.7 \%$; frequency: $74.8 \%$ ) at month 6 .

\section{Discussion}

This analysis aimed to assess whether extended ibandronate dosing was associated with improved GI tolerability in patients who had previously experienced GI irritation with daily or weekly BP use. In both the PRIOR and CURRENT trials, women reported improvement in the GI symptoms they had encountered in previous treatment with daily or weekly BPs. The GI tolerability scores improved significantly for patients

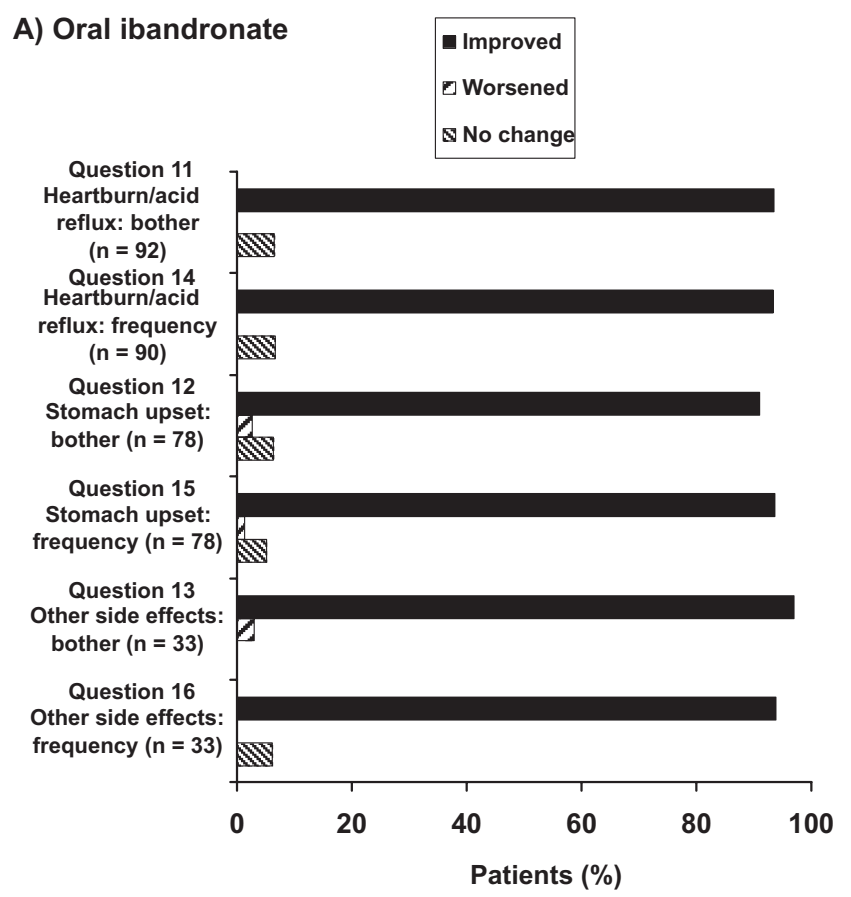

in the PRIOR study, and patients in both studies reported improvements in symptom severity and frequency scores.

Evidence from previous research on the occurrence of GI symptoms associated with oral BP treatment has been mixed. RCTs have generally reported a rate of GI adverse events similar to placebo with all BPs., ${ }^{4,18-21}$ However, after the introduction of daily alendronate, an increase in GI symptoms was reported ${ }^{29,30}$ and results from later studies further supported the link between BP treatment and GI events. ${ }^{12,22}$ BPs have been shown to induce ulceration and necrosis in gastric mucosa. ${ }^{15,29}$ Although the mechanism of BP-induced GI irritation is not well understood, a study in human colon tumor cells suggests that BPs induce apoptosis and/or inhibition of proliferation of epithelial cells. ${ }^{31}$ Another ex vivo study showed evidence of neutrophil accumulation and epithelial damage in the gastric mucosa of rats on contact with high concentrations of alendronate or pamidronate. ${ }^{32}$

In order to minimize contact of BPs with gastric mucosa, the current administration recommendations for orally administered BPs were developed. The dosing instructions for weekly BPs state that the drug should be administered with a glass of water 30 minutes before the first food or beverage of the day and the patient should not lie down within 30 minutes after dosing. ${ }^{16}$ However, despite the changes in the method of administration, recent data suggest

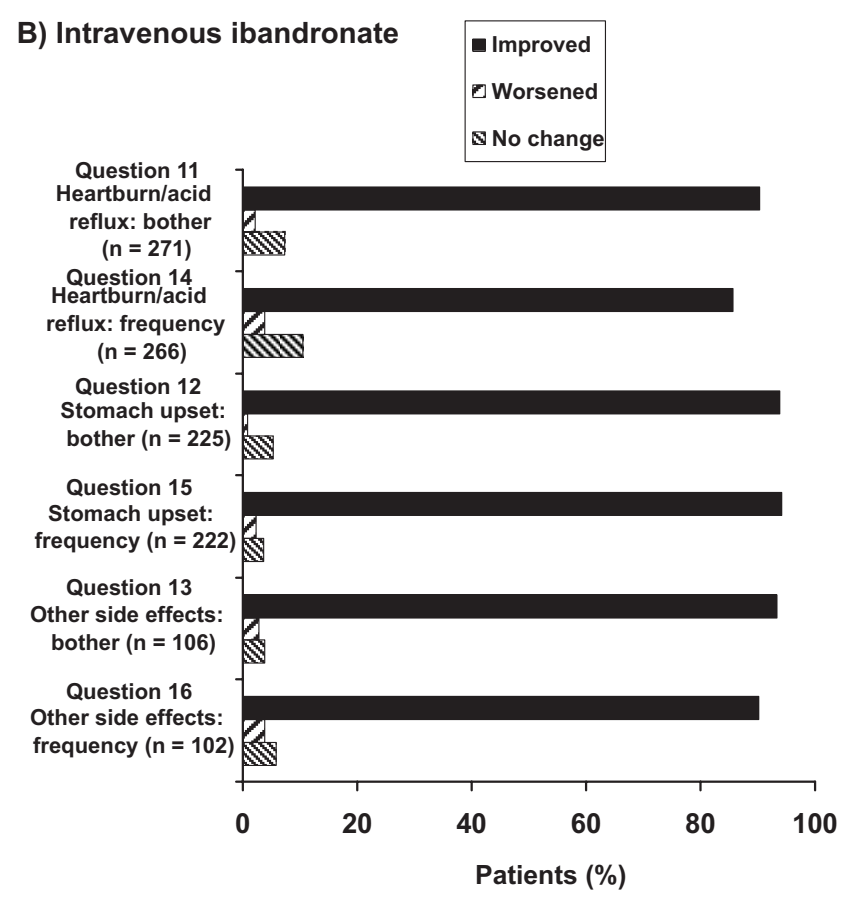

Figure 2 PRIOR: Change in self-reported gastrointestinal symptoms for patients with gastrointestinal symptoms at baseline (score of I-4 on at least I of Osteoporosis Patient Satisfaction Questionnaire ${ }^{\mathrm{TM}}$ questions $\left.1 \mathrm{I}, 12,13,14,15,16\right)$ at Month 10. 


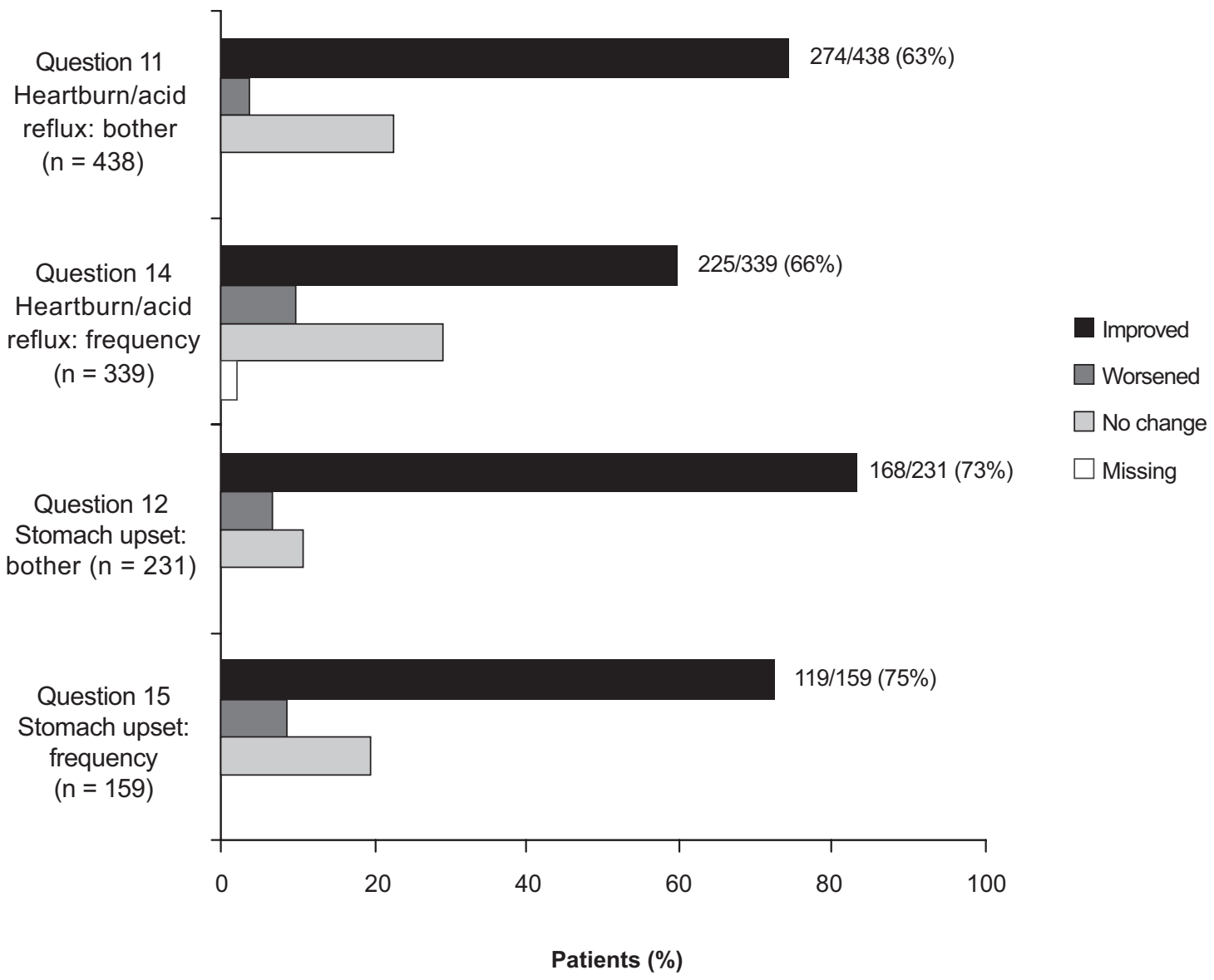

Figure 3 CURRENT: Change in self-reported gastrointestinal symptoms for patients with gastrointestinal symptoms at baseline (score of I-4 on at least I of Osteoporosis Patient Satisfaction Questionnaire ${ }^{\mathrm{TM}}$ questions II, 12, 14, I5) at Month 6.

that GI symptoms still account for a high proportion of discontinuations in clinical practice. ${ }^{12,13}$ IV administration, while requiring an injection, avoids contact of the BP with the gastric mucosa.

In a recent database analysis, fewer severe GI events occurred in patients receiving monthly oral ibandronate compared with weekly BPs, although the incidence of these events was low for all treatments. ${ }^{17}$ In addition, $100 \%$ of patients receiving weekly BPs who had an event discontinued treatment. In contrast, only $44 \%$ of those receiving monthly ibandronate who experienced an event discontinued. A separate analysis has suggested that GI event rates may be lower with risedronate than with alendronate. ${ }^{33}$

There are several possible reasons for the varying findings for BP-related GI events. RCTs employ stringent inclusion and exclusion criteria that exclude patients in poorer health, so the rate of GI symptoms may be lower in RCT populations than in the general population of patients receiving BPs. GI symptoms troublesome enough to prompt discontinuation may not be so severe that patients in an
RCT report them. Furthermore, patients in normal clinical practice may follow administration guidelines less closely than those in an RCT, increasing the risk of GI symptoms. Most RCTs report GI events as adverse events., ${ }^{4,5}, 18$ The questionnaires used in PRIOR and CURRENT, with their specific GI-focused questions, may be a more sensitive tool for identifying GI symptoms than adverse event reporting.

PRIOR and CURRENT included distinct populations, both expected to be at risk of experiencing GI symptoms. Women in the PRIOR study had discontinued previous BP therapy due to GI symptoms, and women in the CURRENT subanalysis had experienced GI symptoms on their current BP before switching to oral ibandronate. Improvements reported in GI symptoms in this at-risk group may have clinical implications for other patients who have discontinued BPs due to GI symptoms or who are experiencing GI irritation with current BP treatment. Initiating monthly oral or quarterly IV ibandronate may be associated with improvement in self-reported GI symptoms. Since occurrence 
of GI events is associated with poor adherence to BP therapy, this may help these patients to persist with BP treatment, and therefore be more likely to realize the benefits of BPs in terms of fracture risk reduction.

The benefits of oral alendronate, risedronate, and ibandronate on fracture risk reduction for patients with postmenopausal osteoporosis were established in studies of daily formulations of each product. Subsequent studies compared the efficacy of longer dosing interval regimens of these products with the corresponding daily formulations in terms of BMD increase, which is associated with reduced fracture risk. Studies of daily alendronate and risedronate demonstrated that these regimens significantly reduce the risk of vertebral and nonvertebral or hip fractures compared with placebo. ${ }^{5,18,20,34,35}$ Ibandronate $2.5 \mathrm{mg}$ daily was shown to significantly reduce the rate of vertebral fractures compared with placebo, ${ }^{4}$ and to significantly reduce the rate of nonvertebral fractures in a high-risk population. ${ }^{36}$ Weekly alendronate, and both weekly and monthly risedronate provide similar cumulative doses to the corresponding daily regimens. For these products, the longer dosing interval regimens produced similar BMD increases from baseline to the corresponding daily formulations. ${ }^{37-39}$ Monthly ibandronate $150 \mathrm{mg}$ provides a higher cumulative dose to ibandronate $2.5 \mathrm{mg}$ daily, and was shown to provide a significantly larger BMD increase. ${ }^{40}$ Recent pooled analyses of individual patient data from ibandronate studies have suggested that higher dose regimens, including monthly oral ibandronate $150 \mathrm{mg}$ reduce the risk of nonvertebral fractures. ${ }^{41,42}$ In a recent database analysis, monthly ibandronate treatment was associated with a similar risk of nonvertebral fracture as weekly BPs. ${ }^{43}$

A few limitations of this investigation should also be noted. The two studies included no comparators. It is not certain what outcomes would have resulted from rechallenge with a weekly BP (PRIOR) or continued treatment (CURRENT). CURRENT and PRIOR were open-label studies, so the possibility of bias being introduced by the inclusion of motivated patients cannot be excluded. The participants in PRIOR had a wide variation in the time between ending their previous treatment and entering the study. The baseline GI tolerance score reflected patients' recollection of GI symptoms associated with previous treatment. The possibility that patients answered the questionnaire differently when reporting symptoms associated with ongoing ibandronate treatment in the study cannot be excluded. The CURRENT subanalysis was a post hoc analysis.
The results from the PRIOR and CURRENT studies suggest that women with GI tolerability issues on a daily or weekly BP regimen may experience improved symptoms with the less frequent dosing regimens of monthly oral or quarterly IV ibandronate. The improved GI tolerability associated with extended ibandronate dosing may help to improve adherence to BP therapy, thus, reducing fracture risk in women with postmenopausal osteoporosis.

\section{Acknowledgments}

The authors thank Andrew Cooper, BSc, of Envision Pharma, Southport, CT for his editorial assistance with this manuscript and Bann-mo Day, PhD, of Roche, Nutley, NJ, who performed the analyses.

\section{Trial registry information}

Details of CURRENT and PRIOR were posted prior to study enrollment and synopses of both studies have been posted on http://www.rochetrials.com/ and may also be accessed through the International Federation of Pharmaceutical Manufacturers and Associations trial portal (IFPMA; http://www.ifpma.org/clinicaltrials.html). The protocol numbers are ML18056 (CURRENT) and ML18058 (PRIOR).

\section{Disclosures}

This study was supported and funded by Roche and GlaxoSmithKline. Dr Derman has received research grants from Bristol-Myers Squibb, Procter and Gamble, and Wyeth; and is a consultant/speaker for Ortho-McNeil, Merck, Roche, Solvay, and Wyeth. Dr Kohles is an employee of Roche. Dr Babbitt has been on the speakers' bureau at Merck, Procter and Gamble, GlaxoSmithKline, Lilly, and Kyphon; and has received research grants from Merck, Procter and Gamble, GlaxoSmithKline, and Lilly. This material was presented at the 56th Annual Meeting of the American College of Obstetricians and Gynecologists; May 3-7, 2008; New Orleans, LA, USA.

\section{References}

1. Eastell R. Treatment of postmenopausal osteoporosis. $N$ Engl J Med. 1998;338(11):736-746.

2. Guyatt GH, Cranney A, Griffith L, et al. Summary of meta-analyses of therapies for postmenopausal osteoporosis and the relationship between bone density and fractures. Endocrinol Metab Clin North Am. 2002;31(3):659-679.

3. Black DM, Thompson DE. The effect of alendronate therapy on osteoporotic fracture in the vertebral fracture arm of the Fracture Intervention Trial. Int J Clin Pract Suppl. 1999;101: $46-50$. 
4. Chesnut CH, Skag A, Christiansen C, et al. Effects of oral ibandronate administered daily or intermittently on fracture risk in postmenopausal osteoporosis. J Bone Miner Res. 2004;19(8):1241-1249.

5. Harris ST, Watts NB, Genant HK, et al. Effects of risedronate treatment on vertebral and nonvertebral fractures in women with postmenopausal osteoporosis: a randomized controlled trial. Vertebral Efficacy With Risedronate Therapy (VERT) Study Group. JAMA. 1999;282(14): 1344-1352.

6. McClung MR. Bisphosphonates in osteoporosis: recent clinical experience. Expert Opin Pharmacother. 2000;1(2):225-238.

7. Chesnut $\mathrm{CH}$. Treating osteoporosis with bisphosphonates and addressing adherence: a review of oral ibandronate. Drugs. 2006;66(10): 1351-1359.

8. Gold DT, Martin BC, Frytak JR, Amonkar MM, Cosman F. A claims database analysis of persistence with alendronate therapy and fracture risk in post-menopausal women with osteoporosis. Curr Med Res Opin. 2007;23(3):585-594.

9. Siris ES, Harris ST, Rosen CJ, et al. Adherence to bisphosphonate therapy and fracture rates in osteoporotic women: Relationship to vertebral and nonvertebral fractures from 2 US claims databases. Mayo Clin Proc. 2006;81(8):1013-1022.

10. van den Boogaard CH, Breekveldt-Postma NS, Borggreve SE, Goettsch WG, Herings RM. Persistent bisphosphonate use and the risk of osteoporotic fractures in clinical practice: A database analysis study. Curr Med Res Opin. 2006;22(9):1757-1764.

11. Ettinger B, Pressman A, Schein J, Chan J, Silver P, Connolly N. Alendronate use among 812 women: prevelance of gastrointestinal complaints, noncompliance with patient instructions, and discontinuation. J Manag Care Pharm. 1998;4(5):488-492.

12. Hamilton B, McCoy K, Taggart H. Tolerability and compliance with risedronate in clinical practice. Osteoporosis Int. 2003;14:256-262.

13. Penning-van Beest FJ, Goettsch WG, Erkens JA, Herings RM. Determinants of persistence with bisphosphonates: a study in women with postmenopausal osteoporosis. Clin Ther. 2006;28(2): 236-242.

14. Lanza FL. Gastrointestinal adverse effects of bisphosphonates: etiology, incidence and prevention. Treat Endocrinol. 2002;1(1): $37-43$.

15. Lichtenberger LM, Romero JJ, Gibson GW, Blank MA. Effect of bisphosphonates on surface hydrophobicity and phosphatidylcholine concentration of rodent gastric mucosa. Dig Dis Sci. 2000;45(9): 1792-1801.

16. Cryer B, Bauer DC. Oral bisphosphonates and upper gastrointestinal tract problems: what is the evidence? Mayo Clin Proc. 2002;77(10):1031-1043.

17. Blumentals WA, Harris ST, Cole RE, Huang L, Silverman SL. Risk of severe gastrointestinal events in women treated with monthly ibandronate or weekly alendronate and risedronate. Ann Pharmacother. 2009;43(4):577-585.

18. Black DM, Thompson DE, Bauer DC, et al. Fracture risk reduction with alendronate in women with osteoporosis: the Fracture Intervention Trial. FIT Research Group. J Clin Endocrinol Metab. 2000;85(11): $4118-4124$

19. Eisman JA, Rizzoli R, Roman-Ivorra J, et al. Upper gastrointestinal and overall tolerability of alendronate once weekly in patients with osteoporosis: results of a randomized, double-blind, placebo-controlled study. Curr Med Res Opin. 2004;20(5):699-705.

20. Pols HA, Felsenberg D, Hanley DA, et al. Multinational, placebocontrolled, randomized trial of the effects of alendronate on bone density and fracture risk in postmenopausal women with low bone mass: results of the FOSIT study. Fosamax International Trial Study Group. Osteoporos Int. 1999;9(5):461-468.

21. Reginster J, Minne HW, Sorensen OH, et al. Randomized trial of the effects of risedronate on vertebral fractures in women with established postmenopausal osteoporosis. Vertebral Efficacy with Risedronate Therapy (VERT) Study Group. Osteoporos Int. 2000; 11(1):83-91.
22. Lanza FL, Hunt RH, Thomson AB, Provenza JM, Blank MA. Endoscopic comparison of esophageal and gastroduodenal effects of risedronate and alendronate in postmenopausal women. Gastroenterology. 2000;119(3):631-638.

23. Boniva (ibandronate sodium) injection US prescribing information. Nutley, NJ: Roche Laboratories Inc; 2007.

24. Boniva (ibandronate sodium) US prescribing information. Nutley, NJ: Roche Laboratories Inc; 2008.

25. Lewiecki EM, Babbitt AM, Piziak VK, Ozturk ZE, Bone HG. Adherence to and gastrointestinal tolerability of monthly oral or quarterly intravenous ibandronate therapy in women with previous intolerance to oral bisphosphonates: a 12-month, open-label, prospective evaluation. Clin Ther. 2008;30(4):605-621.

26. Bonnick SL, Silverman SL, Tanner SB, et al. Patient satisfaction in postmenopausal women treated with a weekly bisphosphonate transitioned to once-monthly ibandronate. $J$ Womens Health. 2009;18(7):935-943.

27. Flood EM, Beusterien KM, Green H, et al. Psychometric evaluation of the Osteoporosis Patient Treatment Satisfaction Questionnaire (OPSAT-Q), a novel measure to assess satisfaction with bisphosphonate treatment in postmenopausal women. Health Qual Life Outcomes. 2006;4:42.

28. Binkley N, Martens MG, Silverman SL, et al. Improved GI tolerability with monthly ibandronate in women previously using weekly bisphosphonates. South Med J. 2009;102(5):486-492.

29. de Groen PC, Lubbe DF, Hirsch LJ, et al. Esophagitis associated with the use of alendronate. N Engl J Med. 1996;335(14): 1016-1021.

30. Ettinger B, Pressman A, Schein J. Clinic visits and hospital admissions for care of acid-related upper gastrointestinal disorders in women using alendronate for osteoporosis. Am J Manage Care. 1998;4(10): 1377-1382.

31. Suri S, Monkkonen J, Taskinen M, et al. Nitrogen-containing bisphosphonates induce apoptosis of Caco-2 cells in vitro by inhibiting the mevalonate pathway: a model of bisphosphonate-induced gastrointestinal toxicity. Bone. 2001;29(4):336-343.

32. Wallace JL, Dicay M, McKnight W, Bastaki S, Blank MA. $\mathrm{N}$-bisphosphonates cause gastric epithelial injury independent of effects on the microcirculation. Aliment Pharmacol Ther. 1999; 13(12): 1675-1682.

33. Miller RG, Bolognese M, Worley K, Solis A, Sheer R. Incidence of gastrointestinal events among bisphosphonate patients in an observational setting. Am J Manag Care. 2004;10(7):S207-S215.

34. Black DM, Cummings SR, Karpf DB, et al. Randomised trial of effect of alendronate on risk of fracture in women with existing vertebral fractures. Fracture Intervention Trial Research Group. Lancet. 1996;348(9041):1535-1541.

35. McClung MR, Geusens P, Miller PD, et al. Effect of risedronate on the risk of hip fracture in elderly women. Hip Intervention Program Study Group. N Engl J Med. 2001;344(5):333-340.

36. Chesnut $\mathrm{CH}$, Ettinger MP, Miller PD, et al. Ibandronate produces significant, similar antifracture efficacy in North American and European women: new clinical findings from BONE. Curr Med Res Opin. 2005;21(3):391-401.

37. Brown JP, Kendler DL, McClung MR, et al. The efficacy and tolerability of risedronate once a week for the treatment of postmenopausal osteoporosis. Calcif Tissue Int. 2002;71(2):103-111.

38. Delmas PD, McClung MR, Zanchetta JR, et al. Efficacy and safety of risedronate $150 \mathrm{mg}$ once a month in the treatment of postmenopausal osteoporosis. Bone. 2008;42(1):36-42.

39. Schnitzer T, Bone HG, Crepaldi G, et al. Therapeutic equivalence of alendronate $70 \mathrm{mg}$ once-weekly and alendronate $10 \mathrm{mg}$ daily in the treatment of osteoporosis. Alendronate Once-weekly Study Group. Aging (Milano). 2002;12:1-12.

40. Reginster JY, Adami S, Lakatos P, et al. Efficacy and tolerability of once-monthly oral ibandronate in postmenopausal osteoporosis: 2-year results from the MOBILE study. Ann Rheum Dis. 2006;65:654-651. 
41. Cranney A, Wells GA, Yetisir E, et al. Ibandronate for the prevention of nonvertebral fractures: a pooled analysis of individual patient data. Osteoporos Int. 2009;20(2):291-297.

42. Harris ST, Blumentals WA, Miller PD. Ibandronate and the risk of non-vertebral and clinical fractures in women with postmenopausal osteoporosis: results of a meta-analysis of phase III studies. Curr Med Res Opin. 2008;24(1):237-245.
43. Harris ST, Reginster JY, Harley C, et al. Risk of fracture in women treated with monthly oral ibandronate or weekly bisphosphonates: The eValuation of IBandronate Efficacy (VIBE) database fracture study. Bone. 2009;44(5):758-765.

\section{Publish your work in this journal}

Clinical Interventions in Aging is an international, peer-reviewed journal focusing on evidence-based reports on the value or lack thereof of treatments intended to prevent or delay the onset of maladaptive correlates of aging in human beings. This journal is indexed on PubMed Central, MedLine, the American Chemical Society's 'Chemical

\section{Dovepress}

Abstracts Service' (CAS), Scopus and the Elsevier Bibliographic databases. The manuscript management system is completely online and includes a very quick and fair peer-review system, which is all easy to use. Visit http://www.dovepress.com/testimonials.php to read real quotes from published authors.

Submit your manuscript here: http://www.dovepress.com/clinical-interventions-in-aging-journal 